\title{
Farm Partnership between Farmers and The Company in Production and Marketing of Vegetables Commodity
}

\author{
Devy Anggita Puspitaningrum* and Siwi Gayatri \\ Faculty of Animal and Agriculture Science, Diponegoro University, Semarang
}

(Received April 15, 2019; Accepted May 14, 2019; Published May 22, 2019)

\begin{abstract}
Farm partnership model between farmers and industries is expected to give advantages in many aspects such as economic, technical, and social. The research aims to analyze the farm partnership model between vegetable farmers and PT. Bumi Sari Lestari company. Primary data were collected using an interview. Secondary data were gotten by documentation. The data were analyzed by the analytical technique. The result shows that the type of partnership between farmers and the company is Inti-Plasma model based on Memorandum of Understanding (MoU) containing the clause if farmers were not able to provide sufficient vegetable, the company would buy directly from the market. The vegetables bought by industry would be cultivated by the farmer and controlled by industry. There are many issues that have to be solved by the farmers and the company. First, farmers will choose a traditional ceremony instead of harvesting the plants. Hence, the vegetables will get rotten. Farmers will prefer to sell their vegetables to the market instead of bringing it to the company when the price gets high in the normal market. Vegetables will get rotten easily during the transportation process to the company. The last is the company needs to make an agreement with the farmers to decide optimal production based on the farm size in order to avoid over production.
\end{abstract}

Keywords: agribusiness, farmer, horticulture, farm partnership

JEL Classification: D19, J54, Q12

\section{INTRODUCTION}

The partnership is a relationship between two or more parties ranging from production to marketing activities (Saptana, Sunarsih, \& Indraningsih, 2017). Partnerships can be implemented by using several models. They are Inti-Plasma (Inti Rakyat Pattern, PIR), subcontracting, general trading, agribusiness operational cooperation, franchise, and agency. The Inti-Plasma model is a relationship between industry and some parties designing company as the provider of land/field, input, technical guidance, and financial support.

In agricultural sector, the implementation of the partnership model will be accompanied by the

\footnotetext{
* Corresponding author email: gayatri.siwi@gmail.com, ISSN 2615-6075 online; ISSN 2615-6946 print @UWG Press, 2019

OJS http://publishing-widyagama.ac.id/ejournal-

v2/index.php/jsed/
}

company's officers that will support technical cultivation, provision of production facilities and credit. Officer assistance is needed by farmers to achieve the expected product quality by market needs (Purnaningsih, Ginting, Slamet, Saefuddin, \& Padmowihardjo, 2006). The subcontracting model is partnership done by farmers in supplying their crops to the company for further marketing. The general trading pattern is a company selling the farmers' products, while the franchise is cooperation in which the right of trading the product is given by franchisor to the franchisee (Qonita, 2012).

The partnership pattern that is established by the company can give benefits in economic, technical and social aspects (Purnaningsih \& Sugihen, 2008). The involvement of farmers in its partnership with companies is able to increase the income of local farmers, to realize government program and also to increase commodity competitiveness. 
Agricultural development in Central Java has several objectives, including optimizing natural resources in a sustainable manner, increasing farmers' income, and meeting the needs of domestic and foreign consumers. Horticulture is an agricultural subsector that has a large contribution to the Gross Regional Domestic Product (GRDP) in Central Java. In 2016, from the five subsectors of agriculture, horticultural crop belonged to the second rank with a contribution of $29 \%$ and the first rank was occupied by food crops with a contribution of $39 \%$ (Statistic Central Department of Central Java). This condition shows that the horticulture sub-sector has an important role in contributing to the GDRP agricultural sector (Irawan, 2016).

In developing the horticulture sector in Central Java and increasing the farmers' economy, the export company, namely PT Bumi Sari Lestari (the company) has shown a significant role to promote partnership cooperation with farmers. It is one of the companies engaged in vegetables and fruits export. The products are various vegetables and fruits such as local and French bean, parsley, lettuce, potato, melon, and zalacca. The fulfillment of export commodities is obtained from farmers which become a partner of the company across Central Java Province.

Based on the description above, a study of implementation toward vegetable farmers' partnership model at the company is chosen. The benefit of the study for farmers is that it can be used as a source of information and consideration for decision making in the company partnership. For the government, it can be used as the input in determining policy and evaluating partnership program.

The purpose of the research is to analyze the implementation of vegetable farmers' partnership at the company.

\section{RESEARCH METHOD}

The research was done at the company located at Jalan Abu Bakrin 115, Sandangsari, RT. 04/08, Madyocondro, Secang, Magelang. This location was chosen because it is the largest exporter company in Central Java. The company has been stable and there are mentoring activities to farmers from the company.

The data were collected by having interviewing some key informants such as the owner, three administration staffs, five field staffs and five farmers for primary data collection. Secondary data were obtained indirectly from documentation (field note and some documents were gotten from the company and farmers).

Data were analyzed by using descriptive techniques. Descriptive is purposed to describe a process including how fact, reality, indication and event are studied. This method emphasizes in the research process because participants' perception become the key. The situation, condition and local context can influence one's perception (Qonita, 2012).

\section{RESULT AND DISCUSSION}

\section{Partnership Process}

The company of PT Bumi Sari Lestari was established on November 19, 2011 with notarial deed No. 13 dated 19 November 2011. The first launched export to Singapore was in 2012. Vegetables exported by the company are cultivated and managed independently by farmers. All vegetables are cultivated on each farmer's field. The cultivation process starts with land processing, planting, conserving to harvesting.

Cultivation is fully handled by farmers under the supervision of the company so that it matches the quality decided by the company. According to Wibowo (2013), the technical process of cultivation in partnership can be cultivated by the farmers themselves under the supervision of the company officers regarding problems that should be resolved.

Vegetables produced by farmers will be taken by using the company's facilities by the company. Vegetables are immediately taken to cool storage to keep the freshness of the vegetables. In the next morning, the vegetables will be sorted, weighed, and packaged. The standard of sorted vegetables is adjusted to Singapore's demand for size, quality, and product quality. Vegetable packaging is done to hold the deterioration process adjusted to the needs of the vegetable itself. Vegetables cultivated 
by farmers are beans, watercress, parsley, and potatoes which will be explained further in the subsections as follows.

\section{a. Bean}

Bean is the primary commodity exported by the company which has superior quality. The company exports $800 \mathrm{~kg}$ beans that have passed sorting for almost every day. Bean is a horticultural plant widely cultivated because of its easy and relatively short cycle cultivation process. There are 2 types of bean that are partnered at the company, namely Kenya Beans and French Beans. Kenya bean is kind of vertically vine plant while French bean belongs to vine growth. The cultivation of these two types of the bean is relatively the same from processing the land to harvesting, but only French beans need water to propagate the roots.

The first thing needed to be prepared in bean cultivation is land preparation to fit the need of bean. The land is raked up by using harrow then beds are made with an area of $100 \mathrm{~cm}$ and a height of $50 \mathrm{~cm}$. The installation of mulch is carried out after 10 days of giving basic fertilizer to neutralize the soil. After the setting, beans mulch is ready to be planted with a spacing of $30 \mathrm{~cm} \times 30$ $\mathrm{cm}$ and for French beans need to add additives before planting. The treatment provided is quite easy with the provision of supplementary fertilizer on the 15th and 30th day after planting and irrigation is carried out during the dry season. Harvesting can be done after 40 days of planting 25 times a day by requiring 2 additional workers from the land owner.

Beans are one of the main commodities exported at the company. Every day this company can export $800 \mathrm{~kg}$ beans which are supplied by several partner groups. In fulfilling the supply, the company made a cropping pattern for all bean farmers in hopes of meeting Singapore's demand. Cropping patterns are arranged so that they can produce every day with a spacing of 2 weeks. The price of beans purchased from the company is Rp. 11000 per kilogram for grade A and Rp. 4500 to Rp. 5000 per kilogram for grade B. Farmers who enter grade $\mathrm{C}$ or Bad Stock (BS) are returned to farmers or can be calculated Rp 1000 per kilogram.

The price is an agreement between the two parties. The criteria for grade $A$ beans are 10 to 14 $\mathrm{cm}$ baby beans, the criteria for grade $\mathrm{B}$ beans are 15 to $16 \mathrm{~cm}$ long beans and large beans are measured 17 to $20 \mathrm{~cm}$. Beans are sorted by farmers first so there are not many Bad Stock (BS) beans, so farmers do not experience losses. The beans that pass the sorting will be packaged to avoid damage during the shipping process with the plastic that has been pressed by using an impulse sealer.

\section{b. Watercress}

Watercress is a horticulture plant that requires a lot of water in its treatment. It grows optimally in the rainy season. The land condition for watercress plants is flooded in $40 \mathrm{~cm}$ height. A good way to cultivate watercress is that the land is first plowed as deep as $20-30 \mathrm{~cm}$ and then it is given basic fertilizer by using manure. After the land is leveled, grooves with hoes with a distance of $30 \mathrm{~cm}$. Then, the seeds are planted to the grooves that have been made. The treatment provided is quite easy with the provision of supplementary fertilizer on the 15th and 30th day after planting and irrigation is applied during dry season. Harvesting can be done after 40 days of planting up to 3-5 harvesting times. One hectare of land area can produce 800 hunch backs which is equivalent to 11.2 quintals per planting period. The rotten of the stem and purple leaves in the dry season become the problem in cultivating watercress.

Watercress delivery is not done every day, depending on the demand of Singapore. The company implements a trading system in purchasing watercress due to uncertain demand. Three days before delivering the product, the company will notify farmers. The price that occurred is an agreement between the two parties namely Rp 6500 per $\mathrm{kg}$ and bad stock is returned to the farmer. This price is much higher than the market price of Rp 1000 per kg. Terms of exportstandard watercress are it has small sticks about 18-20 cm, wide leaves, smooth surface, and fresh green leaves. Watercress that passes the sorting will be packaged by using plastic that has been pressed by using an impulse sealer to avoid damage during the shipping process. The packaging is done with a cardboard box filled with approximately 40 packs of watercress. 


\section{c. Parsley}

Parsley is a plant that has fresh scented leaves known as herbs or garnishes (trimmers in the presentation of food). This plant is widely cultivated in the highlands with an ideal temperature of 15 $23^{\circ} \mathrm{C}$. The good way to cultivate parsley is hoeing the land, giving a basic fertilizer by using manure then making beds with an area of 100 and $30 \mathrm{~cm}$ high. Soil is left for one week and then mulch can be set. $A$ hole is made to the mulch with a spacing of $20 \times 25 \mathrm{~cm}$. The treatment for parsley is carried out 70 days after planting and one harvest has been carried out then second fertilization is carried out in the fourth month. Farmers can produce 300 $\mathrm{kg}$ of parsley per week with an area of $500 \mathrm{~m} 2$.

Parsley shipment is done once a week and obtained by Wonosobo highland farmers. The onetime delivery target is $100-200 \mathrm{~kg}$ at a price of $\mathrm{Rp}$ 8000 per kilogram where the price is fixed between the two parties. The condition of bad stock parsley is yellowing and its leaves are opened. Bad stocks will automatically be discarded because the quality does not match the market demand. Parsley requirements that meet the standards are fresh green leaves and closed leaves. The treatment after sorting is parsley washed with cold water then packing on styrofoam with ice plastic in the upper and middle parts weighing $1.5 \mathrm{~kg}$.

\section{d. Potato}

Potatoes are plants that have a high selling price because of the difficult cultivation process and less production. The process of cultivating potatoes initially is processing the land by plowing with a depth of approximately $30 \mathrm{~cm}$. After finishing the plowing process, the soil is left for 2-3 days, then raked up for $5 \mathrm{~cm}$ deep and let stand for one week. Then kerf is made with a height of $5 \mathrm{~cm}$ and a width of $80 \mathrm{~cm}$ and then manure is given. Before ready to be planted, the potato seeds are stored for three months to find good buds. The treatment of potatoes consists of watering in accordance with soil and weather conditions and controlling pests and herbs by providing pesticides. Then the potatoes are ready to be harvested between 80 120 days. It is needed to consider the age of potato when it is harvested. Before harvesting, potato tubers are dug randomly to check the readiness. A sampling of these tubers should be taken evenly so that they represent each location.

The company sends potatoes to Singapore in 2 days period. The sorted potatoes are grouped into four different sizes namely baby whose diameter between 1-1.5 cm; mini whose diameter between 2-3 cm; $L$ which has a diameter of $4-5 \mathrm{~cm}$, and XL which has a diameter of more than $5 \mathrm{~cm}$. Potatoes are obtained from farmer groups in the Wonosobo highland area. The cultivation of potatoes is quite difficult. It can only produce $10 \mathrm{~kg}$ per hectare every harvest period. Farmers need coordination in the farmer groups to meet the target of sending 30 tons to the company. The price is various for each size. XL size priced at Rp 17000 per kilogram while baby, mini and L are Rp 15000 per kilogram. The potatoes that pass the sorting will be packaged to avoid damage to the shipping process with the plastic that has been pressed by using an impulse sealer. The packaging is done by using a cardboard box filled with approximately 40 packs.

\section{Partnership Model}

The company cooperates with farmers using the Inti-Plasma model. The Inti-Plasma partnership model is a cooperative relationship between company and partner group in which the company becomes an input provider and farmers becomes product supplier of the company. Qonita (2012) stated that the Inti-Plasma model is a relationship between parties which cooperates with partner companies as providers of land, inputs, providing technical guidance, and financing.

The partnership pattern that is implemented in the company is based on the Memorandum of Understanding (MoU) and Trading system. The Memorandum of Understanding (MoU) is an agreement carried out by the company and farmers by supplying the products to the approved company. Agricultural products are based on the natural condition so they cannot be predicted correctly. Sometimes, the production supplied by farmers has not met the demand from Singapore, so the company establishes a trading system. Trading is a way done by the company to fulfill the demand by buying cash from traders. Purnaningsih et al. (2006) stated that the increasing demand for vegetables is not matched by farmers' supply due to crop failures, the quality of products expected by 
consumers is inappropriate and the product sorting process is too restricted.

The number of farmers involved in the partnership is 419 people who are members of 30 farmer groups spread across four production areas. The facilities and infrastructure provided by the company to farmers, namely in the form of seed loans, supervision and technical guidance, and transportation of crops to the company. The seed loan given will be paid after the farmers supply the company by cutting off the crop. Wibowo (2013),stated that the capital or production facilities provided by the company on credit will be returned by deducting from the production.

The company provides agronomist in each region spread across Central Java, i.e. Temanggung and Semarang, Wonosobo, Magelang and Kopeng. The task of this agronomist is to conduct supervision and technical guidance related to the entire cultivation process so that the speck needed is in accordance with the company's request and it passes the sorting process. This is in line with the opinion of Purnaningsih et al. (2006) which stated that the assistance of company officers is needed by farmers to achieve product quality expected by market needs. Transport of harvests is provided by the company using bamboo baskets taken at the production houses of each farmer group.

Based on the interviews with the general administration the partnership program is a problem solver in improving the economic welfare of farmers. The main problem is that farmers, especially farmers in Central Java, are hard-toobtain capital and unstable market access. This is in accordance with the opinion of Sumarjo (2004) which stated that the partnership that exists between partner groups and partner companies has a goal to improve the quality of partner group resources, increase business scale, and grow and improve group capabilities independently.

The company invites horticultural farmers to work together in developing export-based agriculture in Central Java. Farmers have benefited a lot from participating in collaboration with the company. Stable income and clear market access are the main reasons for farmers to follow a partnership with this company (Mayasari, Sinarwati, \& Yuniarta, 2014). The main buyers from the company are three traders from Singapore who will be distributed to supermarkets such as Giant, Hypermarkets, to restaurants and hotels, and to traditional markets in Singapore. Whereas products that do not pass sorting for foreign markets will be marketed in the local area, where local Semarang traders will come to the company's storage warehouse.

Product distribution to Singapore uses two types of transportation. They are flight and sea transportation depending on the condition of the vegetables being sent. For the short-life vegetables such as beans, watercress, and parsley, flight transportation is used to send it every day. The sea transportation route takes about 5 days to get to the destination so it can be used for shipping vegetables with a long-life such as potatoes and fruits.

Vegetables are obtained directly from farmers by first sorted in the production houses of each farmer to avoid too many pieces returning to the farmer. The vegetable will be taken by the company with the facilities provided. Vegetables that have arrived at the the company production warehouse will be stored first in the Cool Storage to maintain freshness of the vegetables then the packaging process will be carried out in the morning. According to Samad (2006), cooling is done to remove heat in vegetables so that it will be slow respired, reduce sensitivity to microbes, and reduce water content. The delivery process is done in the afternoon and in the next morning is the process of sorting, weighing, packaging, and packing carried out by company employees. Importers have many standards set in the demand for vegetables to companies from size, type, and quality.

\section{Partnership Mechanism}

A collaborative partnership between farmers and companies is the result of an agreement between the two parties in which farmers as suppliers of company products and companies as providers of inputs. This agreement will take effect from the first time of signing the agreement until ending with an agreement between the two parties or one of the parties submits a review one month earlier. Purnaningsih et al. (2006) stated that the agreed contract contains the duration of the 
contract, the terms of the contract, the facilities provided, the payment system, the time period and the thing that cancels the contract.

Requirements for farmers who can work together with the company are to be able to cultivate horticulture plants well, produce continuously, and want to obey agreed agreements so that the collaboration runs well. According to Purnaningsih \& Sugihen (2008), the implementation of a partnership model can run properly if both company and farmer groups obey the agreement.

The flow of partnership between the company and farmers as follows: (i) the agronomists of each region will survey the quality of land and farmers that are ready, then the agronomists directly invite farmers to do a partnership with the company; (ii) farmers that are interested in partnering directly will come to the company to make agreements both verbal and written from the results of the collective agreement; (iii) the company provides input loans to farmers in the form of quality seeds and a schedule of cropping patterns to farmers to meet demand; (iv) the agronomist from the company will conduct supervision and guidance in the form of cultivation techniques to control pests and herbs; (v) the farmer will sell all agricultural products that are previously sorted in the production house of each farmer to the company by using transportation provided by the company; (vi) the company will do re-sorting, weighing, packaging, and packing the products of farmers separately so it does not mix the products of farmers with one another; (vii) vegetables that pass the sorting and those that do not pass are weighed and recorded. vegetables that do not qualify for sorting will be deposited in the company for sale to local traders who directly come to the company or can be returned to farmers as requested; and (viii) payments are made one week after selling to the company in accordance with the product obtained.

\section{Agreement in The Partnership}

The partnership is built from the agreement between the two parties. The company is as the core company and farmers is as Plasma farmer. The agreement is made to avoid the harm of one party and the misuse of the cooperation that was established. Purnaningsih et al. (2006) stated that the implementation of cooperation should be based on writing contracts to anticipate fraud and provide mutual benefits to all parties in partnership. So often the agreed quota is not fulfilled for that the company will use a trading system that is buying products directly in local traders. This cooperation agreement is based on the trust of each partner actor. If there is a dispute between the two parties regarding the implementation of this partnership cooperation, it will be resolved by deliberation to reach a consensus.

The validity period of the agreement between partner companies and farmers is since the agreement is signed. It is concluded that two parties or one of them should submit a review of agreement one month earlier. The contract renewal is conducted every two years to adjust changes in prices and demand for products from Singapore. Most of the farmers who work with companies are joined in farmer groups managed by each farmer group leader. The company deals directly with the head of the farmer group in coordinating all vegetable requests. Farmers' products of harvesting will be brought to farmer groups and then marketed by the company with prevailing price agreements.

In a partnership process, there are needs to be cleared about the rights and obligations so that each party knows his responsibilities and duties. Wibowo (2013) stated that the determination of rights and obligations is used as a reference in implementing partnership to run smoothly. If there are forced conditions (force majures) such as natural disaster, fire, and crop failures, the farmer is not obliged to fulfill any sales or compensation obligations to the company.

Managing force majure is to make an agreement by setting aside the selling price of farmers as joint insurance, the amount of which is adjusted to the selling price. The selling price is below Rp 5000,- per kilogram will be set aside Rp 250,- per kilogram while the selling price above Rp 5000,- per kilogram will be set aside Rp 500,- per kilogram. The punishment for farmers who violate are there are warning from agronomists (field facilitators) three times, if the farmer still violates the company will terminate the partnership. The rights and obligations of the company and the farmers in carrying out the partnership as follows: 
Duties and obligations of farmers include: (i) providing a planting schedule and production schedule that will be diversified from the partner the company; (ii) carrying out cultivation activities (beans, parsley, watercress, and potatoes); (iii) providing products (beans, parsley, watercress, and potatoes) according to the production schedule to partner companies of the company in accordance with the agreed quality and price; (iv) accounting for at least $80 \%$ of the estimate, if less than $80 \%$ are caused by unexpected things, then the farmer is obliged to provide information one week in advance; ( $v$ ) the inability of the farmer to fulfill the export quota without notice where the farmer is obliged to provide alternative supply even though the selling price of the other party is higher to meet the quota at the same price; and (vi) the obligation of the farmer to maintain the quality of agricultural products (beans, parsley, watercress, and potatoes) in cultivating according to the standards for the export market and provide reports on the location of the planted and the condition of the land planted every week.

Duties and obligations of the company include: (i) conducting marketing activities for the production of farmers so that in time it is expected that crop yields from farmers can be taken according to a predetermined schedule; and (ii) buying products (beans, parsley, watercress, and potatoes) from the farmers in accordance with the agreement and harvest schedule that has been adjusted to the estimated production every week and pay according to the fixed price.

\section{Benefits in The Partnership}

The partnerships that have been carried out to a large extent have provided benefits in economic, social and technical aspects to both parties. Qonita (2012) stated that the cooperation established in business partnerships between the parties that are partners can provide benefits for both parties. The stable income and clear market access are the main reasons for farmers to follow a partnership with this company.

Since joining the company, farmers feel more comfortable and no worries about marketing their agricultural products. In social terms, partnerships can strengthen the relationship between farmers throughout Central Java. The technical benefit is an increase of technology use and sustainable agriculture. This is in accordance with the opinion of (Purnaningsih \& Sugihen, 2008) which stated that the partnership pattern that is established by companies with farmers can lead to benefits economically, technically, and socially.

The participation of farmers in doing partnerships with the company comes from local Agriculture Service's advice. There are many farmers who have pioneered the success of the company. Unfortunately, some farmers decided to end the collaboration with the company. It is because there is no product that can meet the company's demand and lack of labor, as said by $\mathrm{Mr}$ Ratno (45 years). He prefers to supply to the company on a trading basis because he does not want to be bound by a contract that is considered more difficult to handle. The requirement to become a partner of the company is having experience in farming. The farmer should foster group members and production should be continued.

Cooperation in the partnership will give benefits both for farmers and the company. Farmers will gain market access and increase income. On the other hand companies also get benefits from this activity. The partnership pattern that is applied is the Inti-Plasma where farmers will supply vegetables cultivated on their own land to the core company. The company limitations in providing land to produce profitable products is by establishing this partnership. The core company can still fulfill product demand from Singapore eventhough it does not have land for the production process. The company as a core company in partnership with partner groups has a fostering function. This is in accordance with the opinion of Pusat Penelitian Sosial Ekonomi Pertanian (2001) which stated that the company as a function of fostering is planning, guiding, and serving facilities for production, credit, processing, and marketing.

\section{Problems and Solutions}

The partnership between farmers and the company has gone well although there are some problems that are weaknesses and threats to this partnership model. These problems will cause a lack of consumer trust and loss for farmers and 
companies themselves. According to Purnaningsih \& Sugihen (2008), the obstacles that often occur to farmers are a failure in harvesting, the process of product sorting is very strict, or payment is not paid by the company so it losses farmers. The solution taken in this collaboration is through family consultations which is in line with the agreement.

Based on the results of interviews, there are problems and solutions found in the partnership activities between the company and farmers. First, community habits or customs such as traditional ceremony or celebrations in village that cause production is not on time. This habit will delay farmers in harvesting, so there is no products that can be sold to the company. The solution is the company will buy in the market directly (trading) to fulfill production demand. Second, farmer's preference in selling beans to the market when the price of beans on the market is higher than the company. The solution is the company makes a written agreement regarding the amount of production that should be fulfilled within a certain period of time with fixed prices. Third, the cultivation of beans made by members of the farmer group is not recommended by the company and it causes excessing production of beans. The company required beans of 600 to $800 \mathrm{~kg}$ per day in 2015 while farmers' crop yields were 1400 to $1500 \mathrm{~kg}$ per day in 2016. The condition makes the company spends more money to buy beans from farmers. The solution to this problem is that the company held a mentoring activity to supervise the bean cultivation activities carried out by farmers. Fourth, transporting products still use bamboo baskets which cause damage during the transportation process. The company once lends the facilities to crates, but the facilities provided did not return to the company. The solution to this problem is buying facilities on credit provided by the company.

\section{CONCLUSION AND SUGGESTION}

PT. Bumi Sari Lestari is a fruit and vegetable export company partnering with 419 farmers throughout Central Java. The overall partnership model implemented by the company has gone well. The partnership is implemented in the Inti-Plasma model based on a memorandum of understanding (MoU). Farmers cultivate vegetables commodity under the supervision and the quality standart to meet requirements of the company. The company will buy farmers' products and sell the products directly on the market.

There are many problems in implementing partnership, such as community customs which delay harvesting, farmers preference in doing own selling beans when the price of beans is higher in the market, and the product is not long-lasting especially in the transportation process which causes damage or rotten of the product. The suggestions given to the company are that it should establish the capacity that should be fulfilled by farmers in transporting to the company in a certain period of time so that it can avoid product damage, excess production and supply from the farmer.

\section{REFERENCES}

Irawan, B. (2016). Fluktuasi Harga, Transmisi Harga, dan Marjin Pemasaran Sayuran dan Buah. Analisis Kebijakan Pertanian, 5(4), 358373.

https://doi.org/http://dx.doi.org/10.21082/akp. v5n4.2007.358-373

Mayasari, L. P. R., Sinarwati, N. K., \& Yuniarta, G. A. (2014). Pengaruh Pertumbuhan Ekonomi, Pendapatan Asli Daerah dan Dana Alokasi Umum terhadap Pengalokasian Anggaran Belanja Modal pada Pemerintah Kabupaten Buleleng. E-Journal S1 Ak Universitas Ganesha, 2(1): $\quad . .-. \quad$ Retrieved from https://ejournal.undiksha.ac.id/index.php/S1ak/ article/view/4394

Purnaningsih, N., Ginting, B., Slamet, M., Saefuddin, A., \& Padmowihardjo, S. (2006). Faktor-Faktor Yang Mempengaruhi Adopsi Inovasi Pola Kemitraan Agribisnis Sayuran di Jawa Barat. Jurnal Penyuluhan, 2(2), 33-43. https://doi.org/10.25015/penyuluhan.v2i2.2124

Purnaningsih, N., \& Sugihen, B. G. (2008). Manfaat Keterlibatan Petani Dalam Pola Kemitraan Agribisnis Sayuran di Jawa Barat. Jurnal Penyuluhan, 4(2), 80-91. https://doi.org/10.25015/penyuluhan.v4i2.2173

Pusat Penelitian Sosial Ekonomi Pertanian. (2001). Studi Kebijaksanaan Pengembangan Agribisnis Komoditas Unggulan Hortikultura. Pusat Penelitian dan Pengembangan Sosial Ekonomi Pertanian, Badan Penelitian dan Pengembangan Pertanian, Departemen Pertanian. Retrieved from 
https://books.google.co.id/books?id=VVJyHQAA CAA]

Qonita, A. (2012). Motivasi Kerja Utama Petani Dalam Kemitraan dengan Pusat Pengolahan Kelapa Terpadu di Kabupaten Kulon Progo. SEPA, 9(1), 90-99. Retrieved from https://eprints.uns.ac.id/1463/1/Motivasi-KerjaUtama-Petani.pdf

Samad, M. Y. (2006). Pengaruh Penanganan Pasca Panen Terhadap Mutu Komoditas Hortikultura. Sains Dan Teknologi Indonesia, 8(1), 31-36. Retrieved from http://ejurnal.bppt.go.id/ejurnal2011/index.php Ljsti/article/view/647/597

Saptana, N., Sunarsih, N., \& Indraningsih, K. S. (2017). Mewujudkan Keunggulan Komparatif
Menjadi Keunggulan Kompetitif Melalui Pengembangan Kemitraan Usaha Hortikultura. Forum Penelitian Agro Ekonomi, 24(1), 61-76. https://doi.org/10.21082/fae.v24n1.2006.61-76

Sumarjo. (2004). Teori dan Praktik Kemitraan Agribisnis. Penebar Swadaya. Retrieved from https://books.google.co.id/books?id=YJtFAgAAC AAJ

Wibowo, E. (2013). Pola Kemitraan Antara Petani Tebu Rakyat Kredit (TRK) Dan Mandiri (TRM) Dengan Pabrik Gula Modjopanggoong Tulungagung. Jurnal Manajemen Agribisnis, 13(1), 1-12. Retrieved from http://publikasi.uniska-

kediri.ac.id/data/uniska/agribisnis/agribisnisvol1 3no1jan2013/agribisnis-vol13no1jan2013-01. Edy Wibowo.pdf 